\title{
Analysis of the Inhibiting Factors of Transparency in the Implementation of Local Governance
}

\author{
Aeman \\ Rakhmat \\ Andi Agustang \\ Azikin Soelthan \\ Universitas Negeri Makassar, Makassar, South Sulawesi, Indonesia, Jln. Bonto Langkasa Kampus UNM Gunung Sari \\ Post Code 90222; cv.lapiong24@yahoo.co.id, rakhmat20@gmail.com, andiagust63@gmail.com, asoelthan@gmail.com
}

\section{Doi:10.5901/mjss.2015.v6n6s4p464}

\begin{abstract}
This paper aims at describing the factors that inhibit transparency in local governance in Indonesia. The method used in this research is a qualitative method. The source of the data obtained from documentation and related archives. The informant in the interview was selected by purposive. The informants were the people who know the process of local governance in several areas in Indonesia. The validity of the data used in this paper was by triangulation of sources. It was comparing results of the observations and interviews, as well as comparing the results of the interview and the contents of the different documents. Analysis of the data used is interactive analysis models. The results of this research show that the implementation of local governance in Indonesia has not been fully transparent. Several factors cause it. First, the formulation of a policy of transparency in local governance is a multi-level interpretation. Second, the government officials are not obedient and very arrogant. Third, bureaucratic culture is still influenced by the authoritarian new order system. Fourth, communication in the socialization of policy has not been maximized.
\end{abstract}

Keywords: transparency, local government, policy formulation, government officials' attitude, new order, communications systems.

\section{Introduction}

Transparency is part of the concept of good governance that has been widely embraced in the system of Government in different countries around the world including Indonesia. It is the impact of the change of paradigm, where the government is no longer appreciated as the sole parties who are responsible for nation building. However, cooperation between the various sectors is also needed either government, private or civil society according to their respective role. In this regard, the government creates the role of economic, political and legal environment. The private sector aims at creating jobs in order to increase and encourage public income. Meanwhile, civil society plays a role to build economic, political and social interactions that obey the laws and regulations. Therefore, it creates conducive atmosphere by inviting, coordinating and facilitating groups in society in order to participate or to engage actively in the activities of the economic, social and political.

These requirements are very contrary to the classical Weberian-style system. System of government according to the Weberian is more closed than another system. It seems that the enforcement of the country is only the government affairs while the public is not more as objects of development. Therefore, the public considered the party that does not require the information and does not need to be involved in the development process.

This assumption is now not relevant right now, because the pillar of the country's development is not only the government, but also the community and entrepreneurs. In this context, transparency is the most important factor and is very decisive for the creation of good governance either the central or the regional level. Without transparency, good governance does not exist. Transparency is the essence of good governance. Like a building, good governance has several pillars or principles. From these pillars or principles, transparency becomes the main principles or the main pillars.

Transparent government is a government that can embody trust. In addition, it is the rule of reciprocity (balance) through an intense communication system. The government should provide information and accept the aspirations of the community. For the sake of it, the government should guarantee the existence of access or freedom for everyone. It is to 
obtain information about the organization of the government, especially in relation to the policy process, starting from the process of formulation, implementation, and evaluation, as well as on the results achieved.

In addition, the government should also be more participatory and open. The government should also provide an opportunity to ask people for the criticism, suggestions and responses to the Government that is judged not transparent. Community participation will affect other components of the Government. For example, the orientation of the government is changed from command and control-oriented to demand and public needs-oriented. This orientation would then become the basis for the implementation of the government's role as a facilitator, coordinator, stimulators and entrepreneurship in the development process.

It is in accordance with the principles and purposes of the implementation of regional autonomy. Local governments must provide opportunities and open minded towards the public. One aspect of its importance is to open access of information for the public toward the regional development process.

In the context of Indonesia, real transparency has long been embraced in the system of governance especially in local governance. It is characterized by presenting a number of laws and regulations. For example, Law No. 32 and 33 in 2004 is on Local Autonomy. In this law, local governments were given the authority to manage and build its region. The basic spirit of this legislation is that the government could get closer, faster and more precise in providing service to the public.

In addition, before law No. 32 \& 33 in 2004 was formulated, in fact, principles of transparency in the government implementation have also been regulated in law No. 28 in 1999 on Organizing Clean and Free from Corruption, Collusion, and Nepotism. Furthermore, transparency in government implementation is explicitly arranged in the Law No. 14 in 2008 about information disclosure.

The explanation above shows that in terms of the regulation, the Indonesian government has already had enough desire and intention to realize a transparent government system. However, it is not rare to find the opposite of it in practice organizing government daily. The government seems resistant to the input from the public. Although we do not deny that there are some areas that the government is deeply fused with his public. For example, the Mayor of Solo is led by Joko Widodo, known as blusukan or visitation. The Mayor of Surabaya is Tri Rismaharini. The Mayor of Bandung of West Java province is Ridwan Kamil. The Regent of Bantaeng, South Sulawesi province, is H. M. Nurdin Abdullah. However, their number is certainly not sufficient to represent all regions of Indonesia. There is mostly judged by observers and media as officials who are closed, arrogant and even tend to expertly build an oligarchy or the power as found in several areas in Indonesia.

Transparency in local governance has not realized the meaning of transparency itself in the life of a country substantively. As already mentioned above, transparent government is a government that is reciprocal and not monotonous. Therefore, the nature of governance is indeed a transparent government that truly positioned people as owner of the country. Hence, anything that has been, is being and will be implemented by the government should have been sourced from the public aspirations. However, the facts that occur in the field are the opposite. The transparency in the system of government is only a procedural formality and even it is just a complementary label for democracies. As a result, transparency does not provide a sufficient impact on the creation of local governance that is clean and authoritative. Headline News either in print or electronic media showed that there are about more than 80 percents of districts in Indonesia involved in the corruption case. If we observe the case chronologically, it turns out that most cases occur because of local government programs that are not transparent. It is one proof that the transparency in the system of local governance has not been adequately realized.

In addition, an overview of the implementation of the local government that is not transparent is the phenomenon of the emergence of resistance and reaction from the public and civil society in some areas. They complain a number of local government programs. This response emerges in various forms of protests and demonstrations that continue to occur everywhere. Moreover, it creates a conflict and anarchist action. They are demanding and accusing that the local government is not transparent in making a policy. They feel that they are not involved. Therefore, there is any development program within the real places that is not needed by people in that place.

Formulation of the research presented in this paper is the inhibiting factors of local governance that has not been transparent. This paper aims at discovering and uncovering the inhibiting factors of local governance that has not been transparent. This paper is expected to be a double benefit. Theoretically, it could be the basis for developing a model or theorist for the sake of the realization of solutions for local governance that is transparent. Practically, it is expected to be the subject of government input for both the Center and the regions in order to realize the system of Government that is transparent. 


\section{Review of Related Literature}

The purpose of the establishment of a state in the perspective of public administration is to realize orderly living conditions and to create an atmosphere that is fair for all people. Rasyd (1999) avers that in general there are two objectives of the establishment of the state. The first is enforcing an order. The second is creating a fair atmosphere for all citizens.

The purpose of the state as mentioned above can only be achieved through a system of organizing good governance. One of the main principles of good governance is governance that is transparent. It is governance that is held based on the principle of free flow of information on the various institutional processes so that it is readily available to the public. It is also defined by Notodisoerjo (2002, p. 129). He reveals that the transparency is openness of all actions and policies taken by the government. This statement creates the trust between the existing stakeholders.

Furthermore, Notodisoerjo explained that the principle of transparency is to create a reciprocal trust between the government and the public through the provision of adequate and accurate information. Therefore, the government should guarantee the existence of access or freedom for everyone to obtain information about the organization of the government. It is in relation to information on the policy process, starting from the process of formulation, implementation, and evaluation, as well as the results that are achieved.

However, the effort to implement a transparent government, as described above is certainly not natural. There are many factors that influence the implementation of transparency in policy making. It is clearly illustrated by the Pressman \& Wildafsky. They state that the real policy implementation is not only related to behaviors of administrative that are responsible for implementing the program to achieve the goal but also related to the various benefits, either for political, economic or social. All of them can affect the behavior of all parties, and eventually affect the expected and unexpected impact on a policy that is implemented.

The above opinion asserts that as the deciding stage of the policy process, the implementation of the principles of transparency in the implementation of government cannot be separated from the influence of some factors. Therefore, a good policy in regulating the implementation of transparency in the implementation governance is not a guarantee of the success of the implementation of the policy of transparency.

A similar opinion is also delivered by Grindle and Van Meter \& Van Horn. However, these experts mention that the factor that influences the implementation of policies is real human resources as well as supporting facilities and infrastructure. It is different with the opinion of George Edward III and Van Meter \& Van Horn. They emphasized that the attitude of the executor and communication are the factors affecting the successful or the failed of the policy.

The resources intended are a good human-resource either for quality or quantity as well as other supporting facilities. Meanwhile, the attitude of the executor is obedience or adherence of the officials to implement the policy. Communication is the process of socialization or the transformation of knowledge about policies that is implemented from policy makers to the public as a target group policy.

In addition, the structure of the bureaucracy is also influential in the process of implementation of the policy, as the structure affects the work system of implementer. Siagian (1985, p. 229) reveals that the organization is element of implementation, in which there are two aspects that may affect the success of the implementation of the policies, namely structure and process of organization.

Based on the above description, it can be concluded that the process of policy implementation that regulate the transparency of government is greatly influenced by several things. They are resource, attitude, communication, and organization structure.

\section{Methodology}

The research was used qualitative research methods, the type of approach of Transcendental Phenomenology. The method was used because the phenomenological approach to dealing with the dual reality, namely the first, because it can present a direct relationship between researchers and informants. Second, the phenomenological approach was more accurate to describe the phenomena as well as patterns of face value. Third, because the phenomenological approach was not only a description but also seen as a process of interpretation where researchers make interpretation of the meaning experience of the subject under study. So that, through phenomenological approach, researchers can uncover the essence of who was behind the meaning of transparency of the regional administration. 


\section{Results and Discussion}

As previously mentioned, the principle of transparency is good governance that is universal, and it is occurred in almost all countries in the world, including in Indonesia. Therefore, it can be said there is no good governance without transparency. In order to achieve a transparent government, the government has issued several regulations. The first is the Law Number 32, 2004 about autonomous region. The second is the Law Number 28, 1999 on the implementation of state that is free from corruption, collusion, and nepotism. The third is the Law Number 14, 2008 about information disclosure.

All matters in relation to the transparency of the implementation of government have clearly regulated by the laws and regulations that exist. The first part of the legislation (Legislation No. 14, 2008 paragraph 2 article 1) declares that public information is open, and it can be accessed by every user of public information. Even in paragraph 3 of the same article further reiterates that public information must be obtained by each applicant of public information quickly, on time, a cheap cost and the simple way.

However, in the level of implementation, it has not been adequately realized. Transparency of bureaucracy is seen only as a commodity for political elites. Transparency of bureaucracy just echoed when the elections are taking place. If it has been completed, the principles of transparency of bureaucracy settle under the authority of the winner. The only party that is still echoing bureaucratic transparency after the election is a losing contestant. Even it is not pure aiming to want truly to achieve transparency in bureaucracy. However, it is just for revenge against their political rival who wins the election.

In relation to the above description, there are several factors why transparency in local governance is still difficult to be realized, such as the formulation of policies that are not clear and unequivocal. The articles made are highly interpretive. It is commonly known as rubber articles. In a sense, the article that regulates the transparency or disclosure of information sometimes contains multiple interpretations. Thus, it provides an opportunity for government officials to interpret the real intent and purpose in another way. For example, material that regulates the exempt information is paragraph 17 article point 5 of the Law No. 14 in 2008. It states that the information that must not be given to the applicant is the information that endangers the safety and lives of law enforcement or their families. This statement does not describe the standard of the dangerous condition that is intended. In this case, all people are free to interpret the meaning of the hazardous condition. One of the writers has had personal experience related to it. The writer went to a law enforcement official in the area in West Sulawesi province. He asked, "who are the judges who adjudicate cases of rape that took place in this field?" Officials at the agency said it should not be informed Sir because it is very dangerous." In this case, the lack of clarity in the statement in the legislation of transparency leads to the regional administration in the field of law enforcement that is not transparent.

In addition, the government officials are still very arrogant in providing services. They tend to place themselves as the party that most know, righteous and almighty. Furthermore, they are anti-discussion, anti-advice, and anti-criticism. For example, one of the writers stated that he has asked and described any work that is wrong conducted by the Department of public works and Housing in West Sulawesi province. He said "recently I started to speak, one of the officers in the department immediately said that you do not need to explain to us, because we have to explain to you Sir."

Attitude of apparatus as mentioned above certainly does not reflect the principles of transparency, as it will close the tap for public to give and ask for information. In fact, the transparent government is a government that provides not only information, but also the need to seek information from the public and other stakeholders in formulating policies and improve services.

The bad services as described above will also build a sense of community resistance to the programs launched by the government. In this theory, the government officials do not comply with the policies that regulate the transparency in the implementation of government.

The influence of authoritarian systems of the new order is still very high. Indonesia has ever lived in authoritarian systems of the new order of 32 years. Model in making government policy at that moment is top down. Citizens are only as a target group or object of the development. They do not have the space to express their comments and suggestions to the government. Although the age of reform has been almost two decades, the culture is still embedded in the bureaucratic institutions in major Indonesian local level.

In addition, the small quality of the human resources in the governance gives a contribution to the realization of the inadequate transparency in local governance. A survey conducted by the researchers found that most of the existing government officials do not yet fully understand the meaning transparency in local governance. They only understand the synonyms of the word transparency, but they do not know the definition, and meaning of real transparency.

The above description also relates to the lack of socialization of transparency and laws related. Therefore, most of 
the government officials do not understand how the service should be run transparently. They only understand that that transparent government is a government that only provides information. It does not receive information and aspirations in the form of criticism and suggestions. All government officials in Mamuju regency interviewed by the researchers do not understand what and how exactly the government that is transparent. They claimed that they had not socialized about the meaning of bureaucratic transparency, especially about the legislation about the Freedom of Information. It has not been socialized at all.

The researchers also found that there are still many local governments that have not made the local regulations governing the management system in the area of public information. Furthermore, commission of information as mandated by the laws has not been established. Therefore, the public do not know to whom and how to get the information. The researchers interview the Deputy Head of the Region in one of the areas in the province of West Sulawesi, "is there a Commission information and management system governing the change of information?" He honestly said, "Local Regulations has not been made, but it is being drafted. Hopefully, next year (2014) can be completed ".

The explanation seemed to indicate an indifference to local governments for the implementation of transparent governance. In addition, the researchers found that the local governments, in particular the ruling elites, deliberately sterilize information regarding the development programs to the public. They reasoned that the public in the region does not yet have enough knowledge to understand the development policy taken by the government.

One of the officials of the agency for regional development and planning in one of the areas in the province of West Sulawesi discussed with the researchers. He said, "Knowledge of local society about regional development policy is still not enough to understand the government's policy. Therefore, demonstrations and rallies to protest the policy emerge. It ultimately resulted in the failure of these policies to be implemented".

\section{Conclusion}

Based on the above analysis, it can be concluded that there are several factors that inhibit the transparency in the system of local governance. First, formulation of policies directing the transparency of governance is not clear. Second, there is an arrogance service of government officials. Third, there is an effect of an authoritarian system of government for a new order that linger in bureaucratic institutions in the area. Fourth, there is a lack of quality resources of local government officials caused by a lack of socialization of the concept of transparency and laws related.

\section{References}

Abdullah, Rozali. (2000). Wide Autonomy and Federalism Issue As an Alternative. Jakarta: Raja Grafindo Persada.

Abe, Alexander. (2001). Regional Planning, Strengthening Initiative in the Autonomous Region of the People. Yogyakarta: Lapera Pustaka Utama.

Basuki, Eddy. (2004). Auction Transparency Project As A Means Towards Good Governance (Case Study Transparency Project Auction of Jepara District of Department of Public Works). (Thesis). Available: http://core.ac.uk/download/pdf/11713452.pdf

Chandra, Eka, et al. (2003). Building a Citizens Forum: Implementation and Strengthening Civil Society Participation. Bandung: Akatiga.

Hariandja, Marihout Tua Efendi. (2006). Organizational Behavior: Understanding and Managing Behavior in Organizations. Bandung: UNPAR Press.

Hudoyo. (2000). Principles of Governance in Indonesia. Jakarta: Gramedia Pustaka Utama.

Jones, Charles O. (1996). Introduction to Public Policy (Public Policy. Translated by Ricky Ismanto). Jakarta: Raja Grafindo Persada.

Kaho, Josef Riwu. (2001). Prospects of Regional Autonomy in the Republic of Indonesia, Identification of Some Factors Affecting Implementation. Jakarta: Raja Grafindo Persada.

Mansyur, Achmad. (2010). Advanced Theories of Public Administration. Yogyakarta: Mahakarya Rangkang Educations.

Mardiasmo. (2001). Local Politics Post Regional Autonomy in Indonesia. Yogyakarta: Bagian Penerbitan UGM.

Muttaqin. (2010). Implementation of Transparency in Government Procurement (Case Study on Government of Soppeng District).

Robbins, Stephen P. (1994). Organization Theory: Structure, Design and Applications. Translated by Jusuf daya. Jakarta: Penerbit Arcan.

Sidin. (2002). Toward Renewal Government bureaucracy. Kupang Pos edition on Thursday, 3 October 2002.

Soetrisno, Loekman. (1995). Towards a Participatory of Society. Yogyakarta: Kanisius.

Syafrudin, Ateng. (1993). A guideline of Coordination of Regional Government. Bandung: Citra Aditya Bakti.

Thoha, Miftah. (2004). Bureaucracy and Politics in Indonesia. Jakarta: PT. Raja Grafindo Persada.

Wahab, Solichin Abdul. (1997). Policy Analysis: From Formulation to Implementation of State Policy. Jakarta: Bumi Aksara. 